\title{
THE DEMAND ANALYSIS OF THE BIOGAS PLANT WITH CHP SYSTEM ON SUBSTRATE, THE AIM TO OBTAIN REQUIRED ELECTRICAL AND THERMAL POWER
}

\author{
Andrzej Piętak, Miłosz Meus, Szymon Nitkiewicz \\ University of Warmia and Mazury in Olsztyn \\ Faculty of Technical Sciences \\ Oczapowskiego Street 2, 10-719 Olsztyn, Poland \\ Chair of Mechatronics and Technical and Computer Science Education \\ Stoneczna Street 46 A, 10-710 Olsztyn \\ tel.: 08952451 01, fax:0895245150 \\ e-mail:mechatronika@uwm.edu.pl
}

\begin{abstract}
Due to the ending resources of fossil fuels, as well as instability of the political situation on the world, especially in countries that are their main supplier, governments of poor countries in resources are forced to seek alternative sources of energy.

Currently the most commonly used raw material to produce an electrical and thermal power in Poland are coal and lignite, However, in a result of an increase of their prices and an exacerbated by the EU of regulations about an emission of the greenhouse gas, emerged trends, that aim to transform the energy sector through the implementation of technologies based on alternative energy sources. The main focus is to put on renewable energy sources.

The methodology, which is contained in this paper, presents a way to designation the demand of the biogas plant with CHP system on substrate of agricultural origin, the aim to obtain required electrical and thermal power. Moreover, the paper presents a simplified diagram of anaerobic fermentation, which is the basis of biogas production, as well as an illustrative diagram of a biogas plant with CHP system. In this paper also was mentioned the possibility of application biogas for transportation purposes.
\end{abstract}

Keywords: biogas, biogas plant, CHP system, cogeneration, electrical power, renewable energy, thermal power, transportation

\section{Introduction}

In the last decades, the world has become dependent on conventional fuels, which allow men to use modern amenities (such as electricity) and provide a better level of life. Yet, with the world's population growing and migrating to cities, agricultural and industrial production growing, and transportation systems developing, it is difficult not to notice that all of them reinforce each other's negative impact on the dwindling natural resources, and contribute to the water reservoirs and soil degradation, and an increase in greenhouse gasses emissions.

At the moment, in Europe and all over the world, new political agendas originate to solve the problems, which the human civilization faces nowadays. Dominant solutions focus on reasonable production of goods in processes, which are relatively more efficient and generate fewer threats to the environment. In this context, it is plausible to transform the energy sector of economy, today dominated by conventional technologies based mainly on burning fossil fuels, improving electricity and heat production (cogeneration) processes and promoting technologies based on alternative energy sources. Research into alternative fuel applications focuses primarily on gaseous and liquid fuels. The fuels whose resources are considerable or renewable gain most attention.

As it is necessary for Poland to meet the energy agenda of the European Union, in the recent years we could observe a growing interest in investing in renewable energy resources. Among all 
methods of renewable energy production, the national policy favours biogas and heat and electricity production. The latter takes place during one technological process and is called cogeneration or CHP - Combined Heat and Power.

The cogeneration process is one of the most effective ways to increase the efficiency of transforming chemical energy of fuels, thus saving it, as compared with the process of producing heat and electricity separately. The advantages of CHP production are increasing the energetic efficiency, saving the primary energy and limiting emissions of harmful substances.

How useful biogas is in powering electric appliances is determined by a number of properties, such as:

- heating value,

- Wobbe index

- high resistance to engine detonation (knocking),

- an appropriate speed of air-fuel mixture combustion,

- low content of pollutants and other substances.

The so-called Wobbe index is the main parameter which characterizes the utility of gas with reference to using it in given electric appliances. It also determines a possibility of using various gaseous fuels interchangeably in an appliance.

Biogas is mainly applied in a stationary mode, which means it is used primarily to produce heat and power in cogeneration processes. Optionally, biogas can be used as a fuel to power diesel vehicles or to feed the natural gas distribution grid.

Nevertheless, biogas which is derived in the process of anaerobic digestion cannot be directly applied to fuel vehicle engines, mainly due to the presence of unwanted components, which lower the efficiency of biogas combustion. Thus, biogas has to be purified.

Methane content in biogas for diesel engines cannot be lower than $96 \%$, while the concentration of steam should not be lower than $15 \mathrm{mg} / \mathrm{m}^{3}$, the content of hydrogen sulphide cannot exceed $100 \mathrm{mg} / \mathrm{m}^{3}$. Gas cannot also contain particulates larger than 40 micrometers, since they can thwart the engine's exploitation.

\section{The biogas production process}

Biogas is an energy carrier which is produced from organic substances (biomass) in the process of anaerobic digestion. The latter, being a biological process, takes place where appropriate conditions for methanogenic bacteria are provided. This common natural process is observed for instance in peat bogs, at the bottom of the sea, in liquid manure or in manure.

Physically, biogas constitutes a gaseous solution comprising mainly methane and carbon dioxide, which is shown in Tab. 1 [3].

Tab. 1. The average composition of biogas [3]

\begin{tabular}{|c|c|}
\hline Component & Concentration \\
\hline methane $\left(\mathrm{CH}_{4}\right)$ & $50-75 \%$ \\
\hline carbon dioxide $\left(\mathrm{CO}_{2}\right)$ & $25-45 \%$ \\
\hline hydrogen sulfide $\left(\mathrm{H}_{2} \mathrm{~S}\right)$ & $20-20000 \mathrm{ppm}$ \\
\hline hydrogen $\left(\mathrm{H}_{2}\right)$ & $<1 \%$ \\
\hline carbon monoxide $(\mathrm{CO})$ & $0-2.1 \%$ \\
\hline nitrogen $\left(\mathrm{N}_{2}\right)$ & $<2 \%$ \\
\hline oxygen $\left(\mathrm{O}_{2}\right)$ & $<2 \%$ \\
\hline others & traces \\
\hline
\end{tabular}


Contents of the above components, their qualitative composition and biogas properties depend on many factors, among which the initial composition of the raw material which undergoes biodegradation, humidity of the organic substance, temperature, pressure, and the technique applied in the process count as most important.

It is worth noticing that percentage share of methane in biogas determines the heating value of this fuel, thus the higher its share, the higher calorific value biogas has.

Anaerobic digestion is a process which takes place in stages in the absence of oxygen within an appropriate temperature range (app. $10-70^{\circ} \mathrm{C}$ ). The temperature of the process is the main factor which determines its intensity and the dominant of particular bacteria strains which start the process. Thus the process can be caused by psychrophilic bacteria (growth optimum: $10-20^{\circ} \mathrm{C}$ ), mesophilic bacteria (optimum: $27-35^{\circ} \mathrm{C}$ ) or thermophilic bacteria (optimum: $50-60^{\circ} \mathrm{C}$ ) [7].

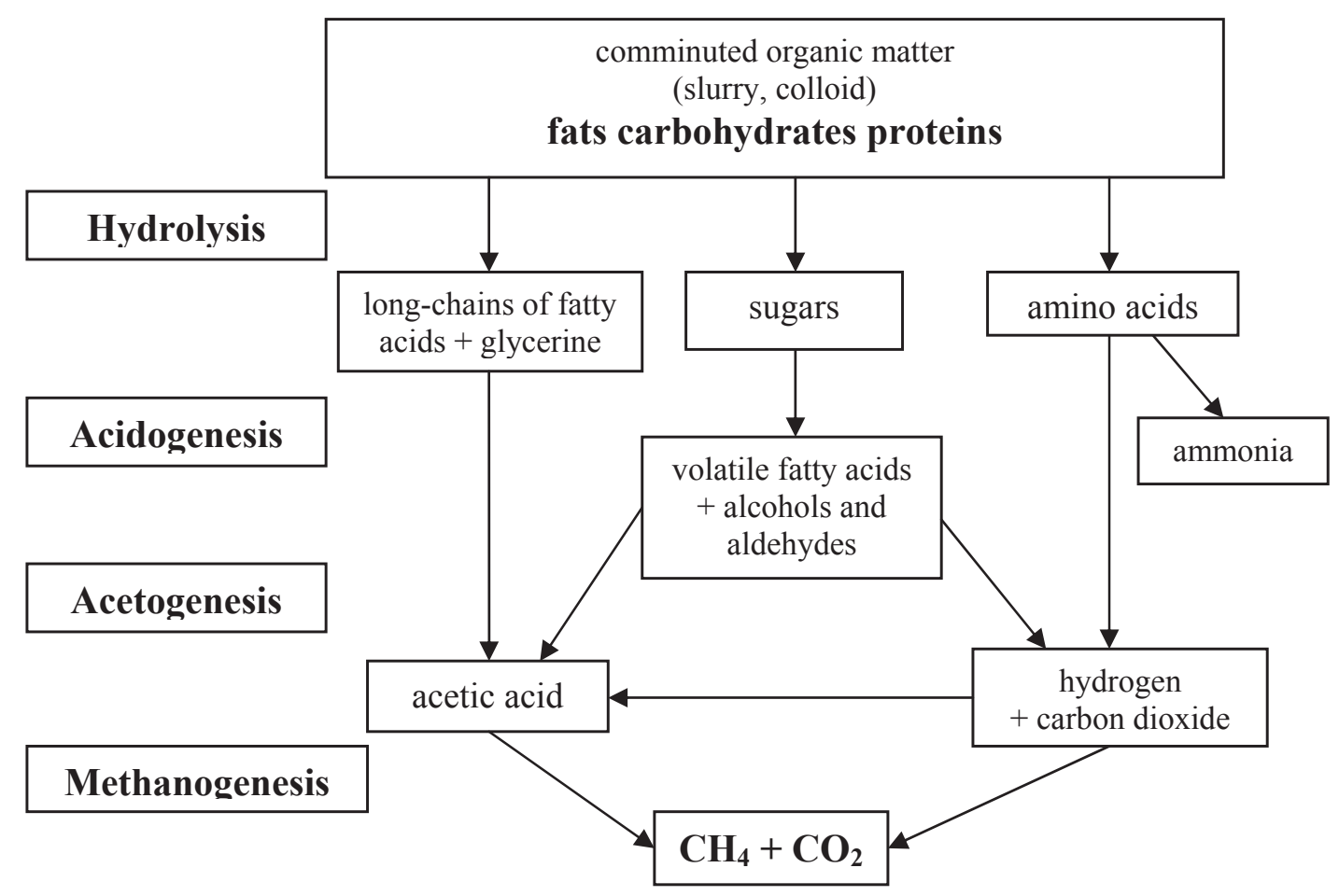

Fig. 1. A simplified diagram of anaerobic digestion process [3-6]

The process in which biogas is produced can be divided into four stages [8]:

- hydrolysis - decomposition of multimolecule chemical compounds to simpler compounds which are soluble,

- acidogenesis - production of short-chain organic acids ( mainly volatile fatty acids), as well as alcohols and aldehydes,

- acetogenesis - production of acetic acid, and $\mathrm{CO}_{2}$ and $\mathrm{H}_{2}$,

- methanogenesis - biogas production $\left(\mathrm{CH}_{4} \mathrm{i} \mathrm{CO}_{2}\right)$.

The stages are schematically presented in Fig. 1. Final products of the whole process comprise biogas as well as solid and liquid stable post-digestion waste, which as a result of subsequent physical and chemical processes transform into useful products - compost, biomethanol, condensed nitrogen, drinking water or others.

A set of devices used to produce and store biogas (digestive chamber with its equipment and a container for biogas) is referred to as biogas plant. If the whole process of digestion takes place in just one digester then we talk about single range plant. The problem here consists in the need to find a compromise, because bacteria have different life requirements at different stages of the digestion process. Methanogenic bacteria, which are most sensitive to any disturbances, develop most slowly, thus it is essential to provide conditions which will be most suitable for these 
organisms. In the second kind of plant - double range one - hydrolysis and acidogenesis are separated by subsequent decomposition ranges. This method makes it possible to adjust the environmental conditions to a chosen group of bacteria thus making the system more efficient.

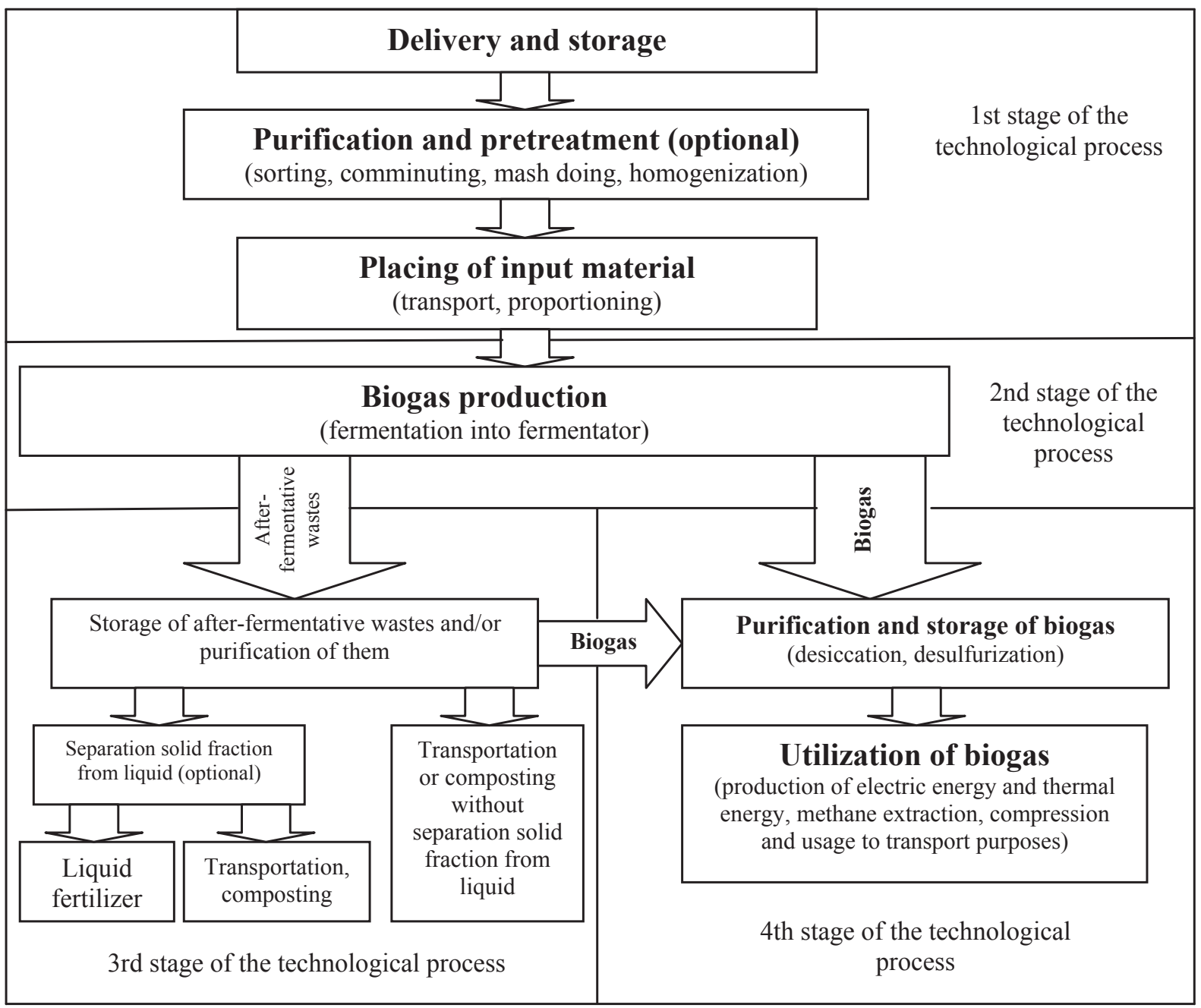

Fig. 2. A biogas production technological process - a general description [1]

Independently of the exploitation type, in the technological cycle of a typical agricultural biogas plant there are four different stages [1]:

1) delivery, storage, treatment, transportation and introduction of substrates,

2) production of biogas,

3) storage and possible purification of post-digestion waste and its removal from the premises,

4) storage, treatment and application of biogas.

All the stages are presented in the above Fig. 2.

The four stages are interdependent. There is an especially strong connection between the second and the fourth stage, since the technological heat required in the second stage is delivered from the fourth one. The following parameters have to appear for the process to be conducted properly:

- absence of oxygen,

- an appropriate temperature,

- a hydraulic retention time,

- optimum volumetric organic batch of the digester chamber,

- an appropriate $\mathrm{pH}$ reaction of the bacteria which take part in all the stages of the process,

- a good contact between bacteria and the medium,

- elimination of inhibitors of the process. 
Among all the mediums used in biogas production, there are agricultural mediums and agricultural industrial mediums.

The mediums of agricultural origin have a huge potential for biogas plant applications, which is shown in Tab. 2.

Tab. 2. The characteristic of substrate of agricultural origin together with the potential of methane production [2].

\begin{tabular}{|c|c|c|c|c|}
\hline & \multirow[t]{2}{*}{ Substrate } & $\begin{array}{l}\text { The percentage } \\
\text { content of dry matter } \\
\text { in } 1 \text { ton of substrate }\end{array}$ & $\begin{array}{l}\text { The percentage } \\
\text { content of dry organic } \\
\text { matter in dry matter }\end{array}$ & $\begin{array}{l}\text { The potential of } \\
\text { methane production } \\
\qquad\left(\mathrm{CH}_{4}\right)\end{array}$ \\
\hline & & $\begin{array}{c}{[\% \text { d.m. } / \text { ton of }} \\
\text { substrate }]\end{array}$ & [\% d.o.m. / d.m.] & {$\left[\mathrm{m}^{3} / \mathrm{t}\right.$ d.o.m] } \\
\hline & liquid manure & 9.5 & 77.4 & 225.5 \\
\hline cattle & manure & 23.7 & 76.4 & 249.4 \\
\hline & urine & 2.1 & 60.0 & 222.5 \\
\hline & liquid manure & 6.6 & 76.1 & 301.0 \\
\hline swine & manure & 23.8 & 79.9 & 228.0 \\
\hline & urine & 2.1 & 60.0 & 222.5 \\
\hline$n$ & liquid manure & 15.0 & 75.6 & 320.0 \\
\hline & manure & 30.3 & 72.7 & 230.0 \\
\hline
\end{tabular}

Due to various mechanisms supporting 'green energy', utilizing biogas in CHP systems and selling thus produced energy to communal grids seem to be the preferred techniques. Nowadays, these are mainly piston diesel engines which are used to do so. Electric energy in a simple and highly efficient way can be transformed into any other form of energy.

\section{The implementation of agricultural biogas plant on the basis of design algorithm}

The issue of retrieving and utilizing biogas to produce energy and the issue of agricultural biogas plants development are complex problems. They encompass topics such as:

- obtaining biomass,

- transportation, storage and preparation of biomass,

- designing a digestion technology depending on the type and composition of the batch,

- choosing optimum process parameters, efficiency and cost assessment,

- assessment of biogas supply in time,

- analysis of biogas composition and properties,

- post-digestion waste processing,

- local and global economic effects analysis,

- legal regulations, etc.

Designing a biogas plant with a CHP system (a cogeneration power aggregate) is not easy, since it requires defining many data before starting the construction works. In the first place, it is necessary to focus on the very biogas installation and determine:

- the kind, amount and quality of the substrate,

- the variant of the biogas production method,

- process parameters in the context of environmental conditions,

- characteristics of the technological process of biogas production,

- the elements of biogas installation. 
On the basis of the above data it is feasible to design a concept project. As a result, it is possible to learn about:

- the predicted biogas amount to be produced,

- the size of installation elements,

- the technological scheme of the process,

- the scheme of biogas plant,

- the predicted costs of the project.

In every case, it is required to decide which technology would be the best in a given situation. Depending on the substrate, it is necessary to determine the technology which would allow to ensure the biogas plant performance in as stable manner as possible.

In the next stage, the very cogeneration module (CHP system) is in focus. Its size depends on the amount of biogas which is produced by the biogas plant and on the amount of time the system is to work in one day, as well as the biogas share in the whole amount of energy and heat the household needs. A simplified scheme of the whole installation is presented in Fig. 3.

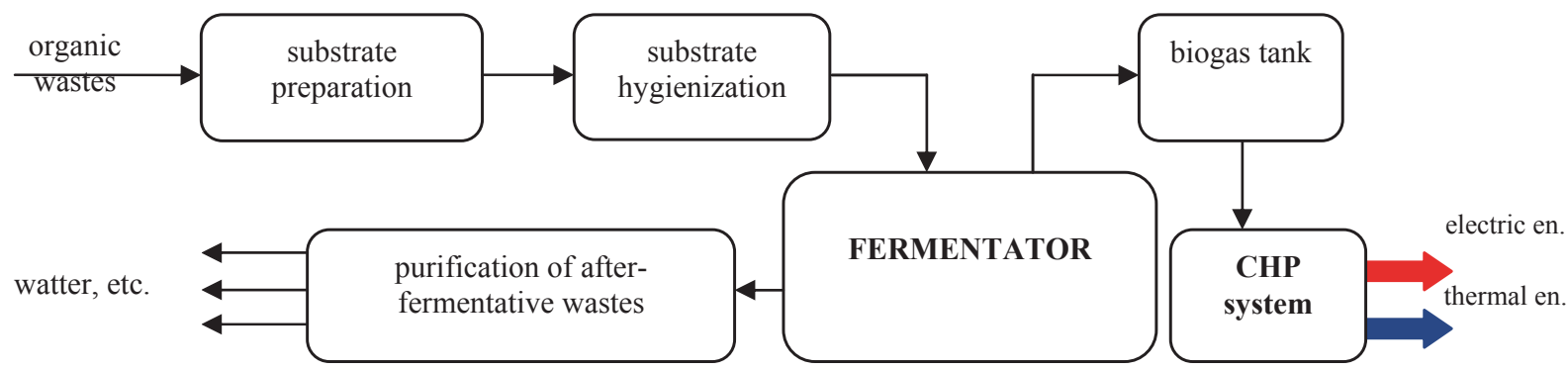

Fig. 3. A schematic view of biogas plant with the CHP system. [the authors' own resources]

On the basis of these assumptions, main elements of the cogeneration system are chosen:

- a gas engine,

- 3-phase synchronic generator,

- a resonator,

- an inside air circulation system,

- a gas exhaust purification system,

- an ignition system (batteries),

- a control cabinet.

It is possible to draw a simplified sketch of the cogeneration module, as shown in Fig. 4.

The above description presents a standard process of designing a biogas installation with a CHP system. Yet, sometimes calculations have to be done starting from the final data, which methodology will be presented below.

It is advisable to start from determining a few data, such as:

- parameters of the cogeneration aggregate:

- mechanical power at $100 \%$ load at the level of $47 \mathrm{kWm}$,

- electric power at $100 \%$ load at the level of $44 \mathrm{kWe}$,

- heating power at $100 \%$ load at the level of $63 \mathrm{kWt}$,

- fuel consumption at $100 \%$ load at the level of $13 \mathrm{~m} 3 / \mathrm{h}$,

- the fuel - natural gas,

- the assumed service cycle $-8760 \mathrm{~h}$.

- agricultural substrates - produced by one animal per year.

On the basis of the above ideas, it is possible to write a general algorithm on how to proceed when designing a biogas installation, starting from a CHP module, which is presented in the following Fig. 5. 


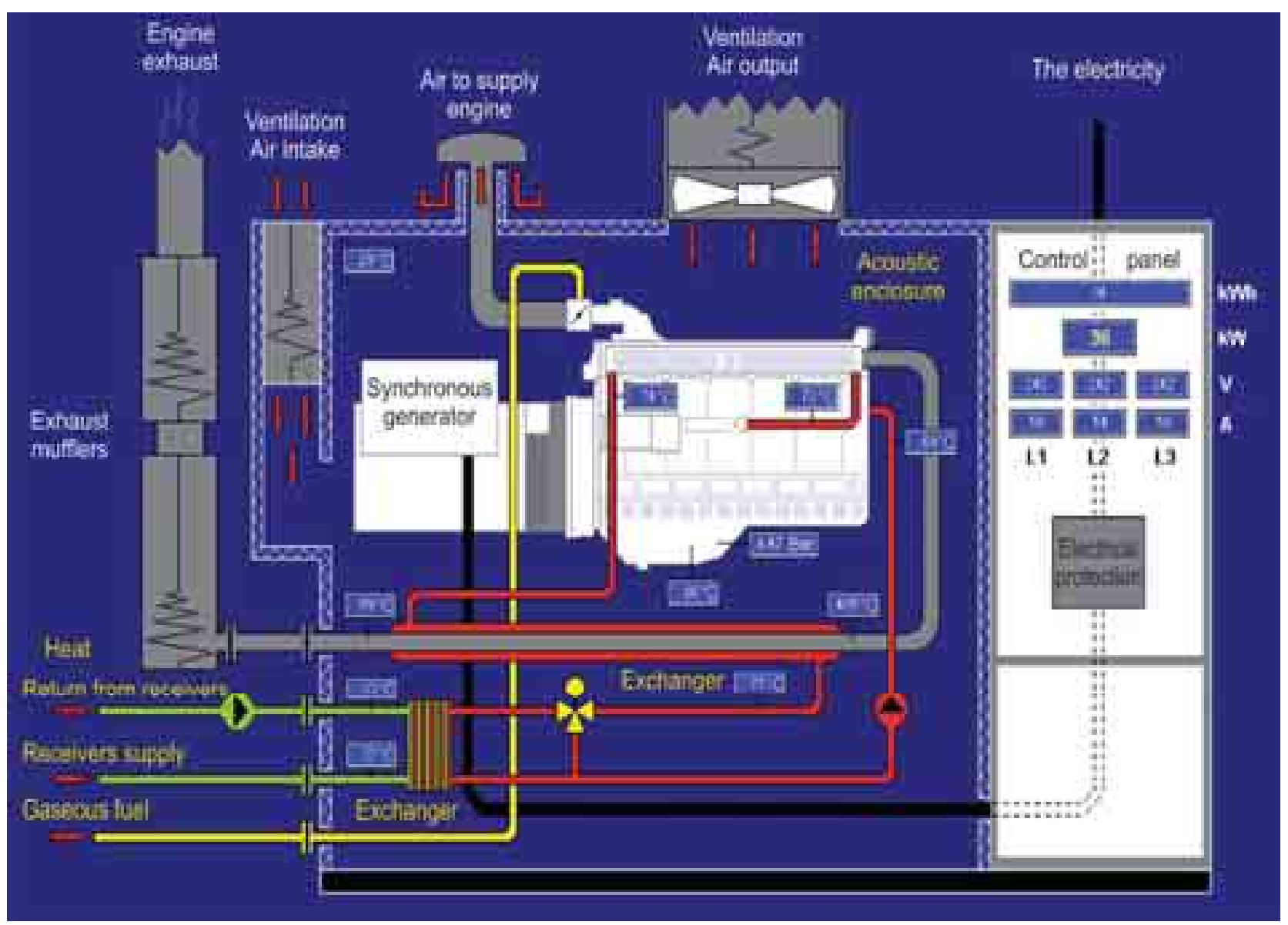

Fig. 4. The pictorial diagram of cogeneration system for electric and thermal energy [15]

The calculations which are presented in Fig. 6 were done on the basis of the above central module of the algorithm and on the example of substrates from cattle, swine and poultry.

Having completed the calculations for the above algorithm, one can choose technical equipment necessary to follow the process in a given plant. First of all, the choice is governed by the availability of substrates. The quantity of these substrates determines the size of all aggregates and containers. The quality of the substrates (dry mass content, structure, origin, etc.) in turn determines the process technique and its application. Depending on the composition of substrates, it might become necessary to separate foreign bodies or prepare mash from the substrates and water in order to make it possible to pump them.

Hydrogen sulphide is a protein decomposition product. Although it appears only in small quantities in biogas, it poses a lot of technical problems. It can cause corrosion of pipelines, fittings and metal containers, thus it is essential to remove it. Another problematic element in biogas, i.e. steam, can condense in pipelines and can cause their blocking. The remaining additions in biogas appear in trace quantities and do not have a considerable impact on its properties.

\section{An average farm animals waste energy production potential in the Province of Warmia and Mazury}

The number of farm animals (from data at the end of 2011) and the potential to produce energy are presented in Tab. 3. The calculations were performed with the assumption that all the animals were subject to one rearing method. 
Tab. 3 The number of farm animals, condition at the end of 2011 year, with the potential of energy production [the authors' own resources]

\begin{tabular}{|c|c|c|c|c|c|}
\hline Farm animals & $\begin{array}{l}\text { Quantity } \\
\text { [piece] }\end{array}$ & \multicolumn{3}{|c|}{$\begin{array}{l}\text { The potential of energy production } \\
{[\mathrm{GWh} / \mathrm{r}]}\end{array}$} & \multirow{2}{*}{$\begin{array}{c}\text { Average value } \\
{[\quad[\mathrm{GWh} / \mathrm{r}]}\end{array}$} \\
\hline \multicolumn{2}{|l|}{ System of keeping } & $\mathrm{DB}$ & SB & WB & \\
\hline Cattle & 427800 & 2745.25 & 1544.23 & 1324.36 & 1871.28 \\
\hline cows & 213600 & 1592.14 & 915.47 & 738.12 & 1081.91 \\
\hline Swine & 608600 & 888.38 & 383.08 & 192.15 & 487.87 \\
\hline piglets up to $20 \mathrm{~kg}$ & 167300 & 79.82 & 16.82 & 10.54 & 35.73 \\
\hline young pigs from $20 \mathrm{~kg}$ to $50 \mathrm{~kg}$ & 161600 & 160.62 & 10.58 & 34.62 & 68.61 \\
\hline Swine (50 kg and more) & 218800 & 478.45 & 260.96 & 111.68 & 283.70 \\
\hline Sows & 60900 & 169.49 & 94.71 & 35.31 & 99.84 \\
\hline Poultry & 7010300 & - & 140.05 & - & 140.05 \\
\hline hens & 3045000 & - & 63.66 & - & 63.66 \\
\hline
\end{tabular}

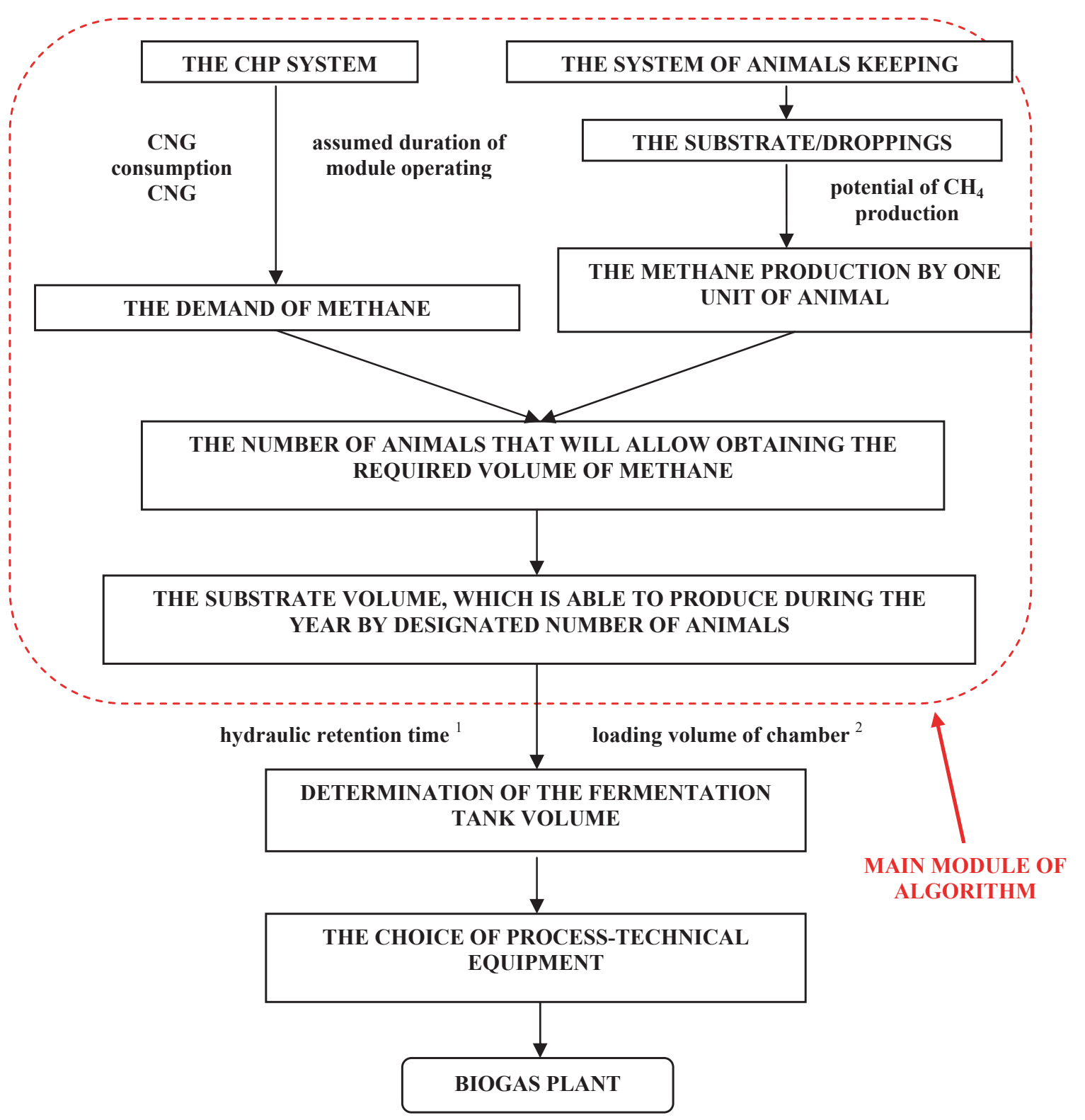

Fig. 5. The general design algorithm of biogas installation [the authors' own resources]. 1 - The time, in which the substrate remains in fermentation tank, until to distribution. 2 - The quantity of dry organic matter, which must be provided on the volume of $1 \mathrm{~m}^{3}$ to fermentation tank within one day 


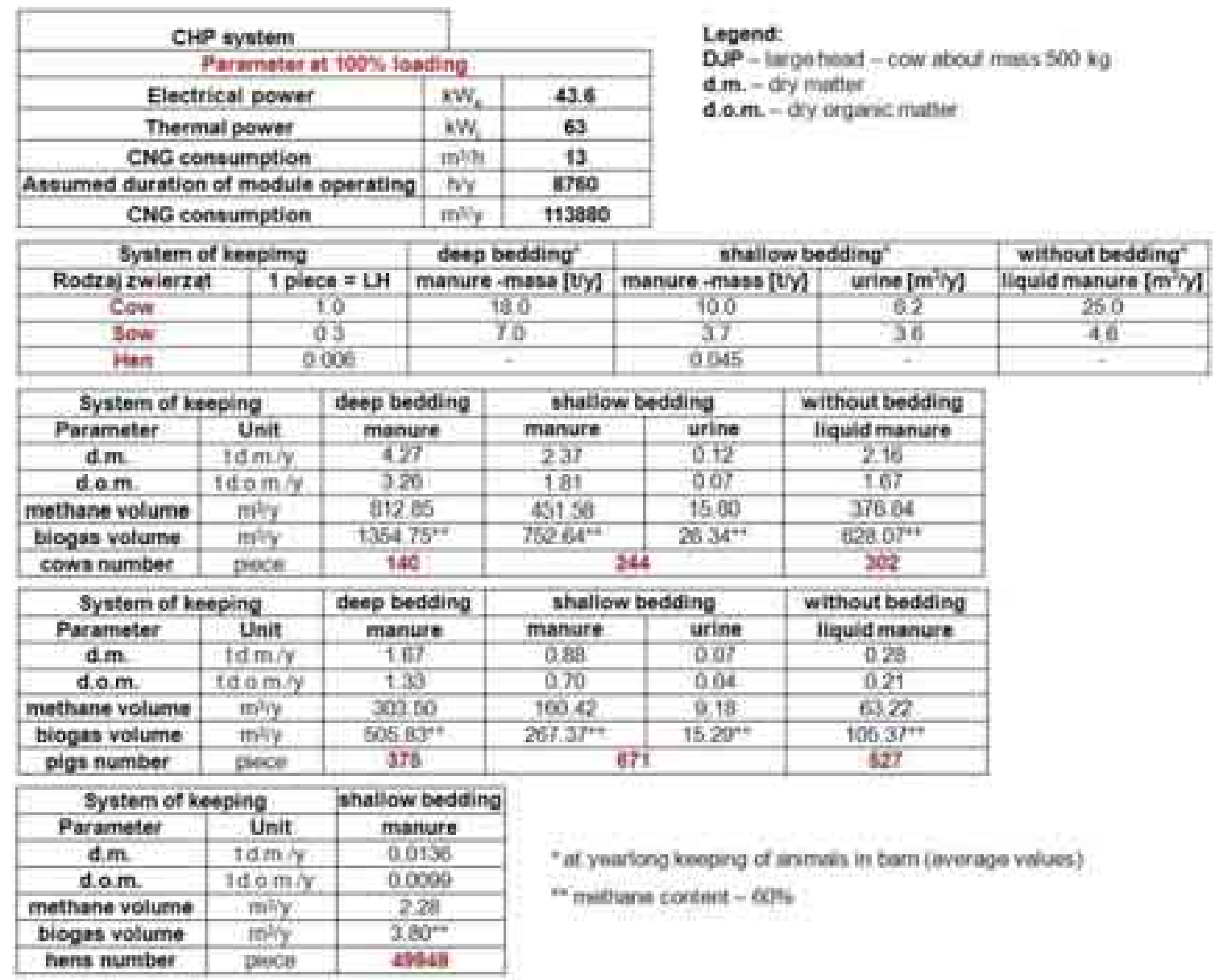

Fig. 6. The exemplary result of realization main module of algorithm [the authors' own resources]

\section{Conclusions}

Implementing biogas installations bring many positive results, mainly in terms of ecology. The greatest benefits comprise reduction of uncontrolled emissions of greenhouse gases (since the waste is used to produce fuel) as well as reduction of pollution emissions (since this fuel is used to produce energy, replacing fossil fuels).

The stable and efficient fertilizer which is produced in biogas plants ensures recycling nutritious substances in soil and diminishes the use of chemical fertilizers. If manure is not used as a fertilizer, the risk of spreading biological threats and polluting ground water and soil is lower.

Biogas plants perfectly match the idea of ecological (balanced) farming, giving individual farmers a chance to fulfill their energy consumption needs (and optionally to sell the excess) and facilitating reusing nutrients to fertilize soil when waste is utilized. At the same time, it is possible to gain financial profits, i.e. save money as described above, as well as selling high quality goods (electric energy, fertilizing concentrate), commercially utilizing waste, and performing other activities such as trading $\mathrm{CO}_{2}$ credits. The financial success however, is conditioned by the scale of the enterprise, its logistics and an appropriate choice of technologies.

Numerous potential ecological, energy related, and financial benefits of anaerobic biodegradation have instilled more interest concerning such technologies also in Poland. The main obstacles they meet in our country are of financial nature, i.e. high investment costs, unfavourable structure of our agriculture, no effective examples of successful implementations of such technologies, too little or too difficult to achieve financial support for investments and scientific research into the development of the existing technologies.

The presented example of methodology of determining the biogas plant's demand for 
agricultural substrates used to produce energy in CHP systems can be implemented also to produce biogas from communal waste or food production substrates.

Biogas can also be used in transportation, after a certain preparation procedure. First, it has to be purified, then methane is to be extracted, and finally it has to be compressed to be applied in vehicles.

\section{References}

[1] Jäkel, K., Landwirtschaftliche Biogaserzeugung und - verwertung, Sächsische Landesanstalt für Landwirtschaft 1998/2002.

[2] Schulz, H., Eder, B., Biogas Praxis, Grundlagen, Planung, Anlagenbau, Beispiele, Ökobuch Verlag, Staufen bei Freiburg 2001.

[3] Kaltschmitt, M., Hartmann H., Energie aus Biomasse - Grundlagen, Techniken und Verfahren, Springer Verlag Berlin, Heidelberg, New York 2001.

[4] Braun, R., Biogas - Methangärung organischer Abfallstoffe, Springer Verlag Wien, New York 1982.

[5] Kloss, R., Planung von Biogasanlagen, Oldenbourg Verlag München, Wien 1986.

[6] Schattner, S., Gronauer, A., Methangärung verschiedener Substrate - Kenntnisstand und offene Fragen, Gülzower Fachgespräche, T. 15, Energetische Nutzung.

[7] Piątek, R., Produkcja i energetyczne wykorzystanie biogazu - przykłady nowoczesnych technologii, Konferencji Naukowo-Technicznej pt. Odnawialne źródła energii w województwie śląskim. Zasoby, techniki i technologie oraz systemy wykorzystania OŹE, Katowice 2005.

[8] Fukas-Płonka, Ł., Biogaz z osadów ściekowych, Paliwa z odpadów, T. 2, Praca zbiorowa pod redakcją J. W. Wandrasza i J. Nadziakiewicza., Wydawnictwo Helion, Gliwice 2001.

[9] Gospodarka paliwowo-energetyczna w latach 2008-2009, Główny Urząd Statystyczny, Warszawa 2010.

[10] Gronowicz, J., Ochrona środowiska w transporcie lądowym, Poznań - Radom 2004.

[11] Ministerstwo Rolnictwa i Rozwoju Wsi Ministerstwo Srodowiska, Kodeks dobrej praktyki rolniczej, załączniki.

[12] Mazowiecka Agencja Energetyczna Sp. z o.o., Biogaz rolniczy - produkcja i wykorzystanie, Warszawa 2009.

[13] Inspekcja Ochrony Środowiska, Wojewódzki Inspektorat Ochrony Środowiska w Szczecinie, Analiza oddziaływania rolnictwa na środowisko wodne $w$ województwie zachodniopomorskim potencjalne ograniczenia w rozwoju produkcji zwierzęcej, Szczecin 2005.

[14] Biuletyn statystyczny województwa Warmińsko-Mazurskiego, I kwartał 2012, Olsztyn 2012.

[15] VIESSMAN, Kogeneracja w oparciu o gaz ziemny oraz biogaz, Zakopane 2010.

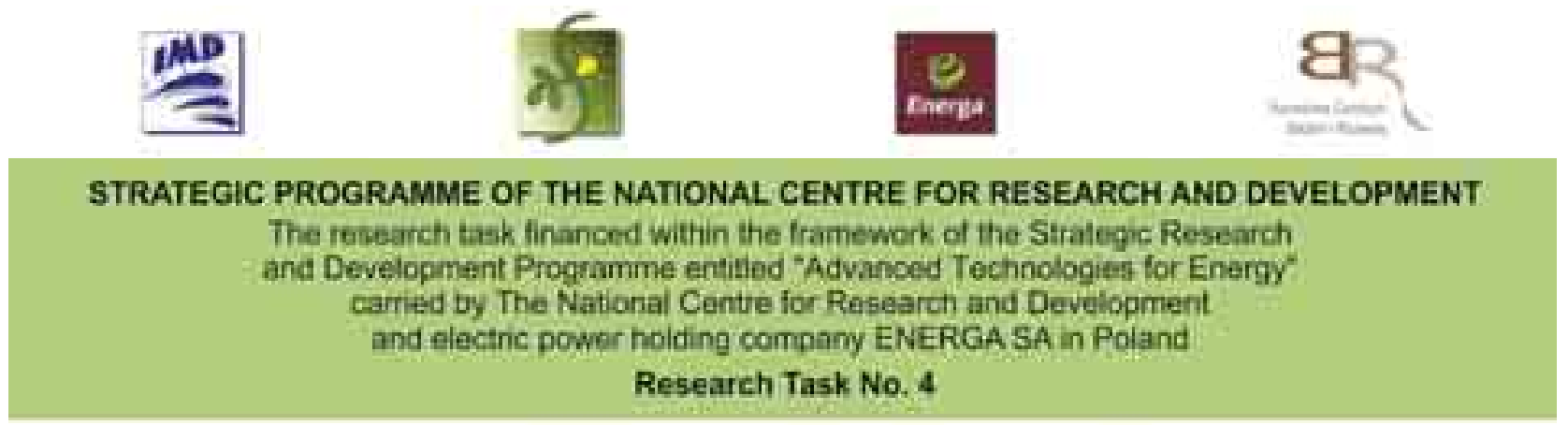

DEVELOPMENT OF INTEGRATED TECHNOLOGY OF FUELS AND ENERGY FROM BIOMASS, AGRICULTURAL WASTE AND OTHER 